\title{
Interplay between Inflammation and Stemness in Cancer Cells: The Role of Toll-Like Receptor Signaling
}

\author{
Da-Wei Yeh, ${ }^{1}$ Li-Rung Huang, ${ }^{2}$ Ya-Wen Chen, ${ }^{3}$ \\ Chi-Ying F. Huang, ${ }^{4}$ and Tsung-Hsien Chuang ${ }^{1,5}$ \\ ${ }^{1}$ Immunology Research Center, National Health Research Institutes, Miaoli 35053, Taiwan \\ ${ }^{2}$ Institute of Molecular and Genomic Medicine, National Health Research Institutes, Miaoli 35053, Taiwan \\ ${ }^{3}$ National Institute of Cancer Research, National Health Research Institutes, Miaoli 35053, Taiwan \\ ${ }^{4}$ Institute of Biopharmaceutical Sciences, National Yang-Ming University, Taipei 11221, Taiwan \\ ${ }^{5}$ Program in Environmental and Occupational Medicine, Kaohsiung Medical University, Kaohsiung 807, Taiwan
}

Correspondence should be addressed to Tsung-Hsien Chuang; thchuang@nhri.org.tw

Received 18 September 2016; Revised 22 November 2016; Accepted 5 December 2016

Academic Editor: Andréia M. Cardoso

Copyright (C) 2016 Da-Wei Yeh et al. This is an open access article distributed under the Creative Commons Attribution License, which permits unrestricted use, distribution, and reproduction in any medium, provided the original work is properly cited.

\begin{abstract}
Cancer stem cells (CSCs) are a small population of cancer cells that exhibit stemness. These cells contribute to cancer metastasis, treatment resistance, and relapse following therapy; therefore, they may cause malignancy and reduce the success of cancer treatment. Nuclear factor kappa B- (NF- $\kappa \mathrm{B}-$ ) mediated inflammatory responses increase stemness in cancer cells, and CSCs constitutively exhibit higher NF- $\kappa \mathrm{B}$ activation, which in turn increases their stemness. These opposite effects form a positive feedback loop that further amplifies inflammation and stemness in cancer cells, thereby expanding CSC populations in the tumor. Toll-like receptors (TLRs) activate NF- $\kappa$ B-mediated inflammatory responses when stimulated by carcinogenic microbes and endogenous molecules released from cells killed during cancer treatment. NF- $\kappa$ B activation by extrinsic TLR ligands increases stemness in cancer cells. Moreover, it was recently shown that increased NF- $\kappa$ B activity and inflammatory responses in CSCs may be caused by altered TLR signaling during the enrichment of stemness in cancer cells. Thus, the activation of TLR signaling by extrinsic and intrinsic factors drives a positive interplay between inflammation and stemness in cancer cells.
\end{abstract}

\section{Introduction}

Inflammation is a hallmark of cancer development $[1,2]$. Chronic inflammation caused by exposure to environmental agents, infection, genetic disease, and metabolic disorders is closely associated with several tumors, including lung carcinoma, hepatocellular carcinoma (HCC), gastric cancer, cervical cancer, colorectal cancer, Hodgkin's disease, and multiple myelomas $[3,4]$.

The tumor microenvironment comprises cancer cells, cancer stem cells (CSCs), endothelial cells, and immune cells, such as tumor-associated macrophages, tumor-associated neutrophils, lymphocytes, and other stromal cells, such as cancer-associated fibroblasts $[2,5]$. Inflammatory stimuli, such as the toll-like receptor (TLR) agonists, tumor necrosis factor- (TNF-) $\alpha$, and interleukin- (IL-) 1 , activate NF- $\kappa$ B in tumor cells $[6,7]$. Activated NF- $\kappa$ B induces the transcription of multiple proinflammatory genes and is a key mediator of acute and chronic inflammatory responses in tumor cells and the tumor microenvironment $[3,8]$. NF- $\kappa \mathrm{B}$-mediated proinflammatory programs link cancer-related inflammation with carcinogenic processes, including tumor initiation, tumor promotion, and metastasis. NF- $\kappa \mathrm{B}$ induces the expression of genes that regulate apoptosis, angiogenesis, proliferation, survival, and cancer cell invasion. These NF- $\kappa \mathrm{B}$-mediated responses also rehabilitate the inflammatory tumor microenvironment, further supporting tumor progression [9-11].

CSCs are a small population of cancer cells with enriched stemness and tumor-initiating ability in the tumor microenvironment. CSCs possess self-renewal and differentiation abilities, which promote tumor progression and metastasis and are responsible for treatment resistance and cancer relapse [12-16]. In addition to supporting angiogenesis, proliferation, and cancer cell survival, NF- $\kappa$ B-mediated 
inflammatory responses also support CSC expansion. NF$\kappa \mathrm{B}$ activation induces the expression of stemness-associated genes and regulators of the epithelial-mesenchymal transition (EMT) in cancer cells, thereby generating a CSC phenotype [17-19]. In contrast, together with increased stemness, CSCs exhibit an elevated expression of inflammatory genes due to elevated NF- $\kappa$ B activation [20-23]. This interplay between inflammation and stemness could enhance these two properties of cancer cells to further expand the CSC population. CSCs may cause malignancy and reduce the success of cancer treatments; therefore, the molecular mechanisms underlying the interplay between inflammation and stemness should be further investigated in cancer cells.

TLRs are a family of receptors that sense pathogenassociated molecular patterns (PAMPs) of microbes and danger-associated molecular patterns (DAMPs) released from damaged tissues or cells killed during different cancer therapies [24-26]. TLR signaling triggers NF- $\kappa \mathrm{B}$ activation and inflammatory responses [27, 28]. In this review, we discuss the current knowledge on the function and mechanisms of TLR signaling in the bidirectional interplay between inflammation and stemness in cancer cells.

\section{TLRs}

Toll is a type I transmembrane receptor that was originally identified in Drosophila for its involvement in embryo development [29]. In the adult fly, toll plays a crucial role in innate immune responses to microbial infections. Thirteen TLRs have been identified in mammals, 10 of which (TLR1TLR10) are expressed in humans. The 10 human TLRs share common structural features: an extracellular domain comprising multiple leucine-rich repeats, a transmembrane region, and a highly conserved cytoplasmic toll/IL-1 receptor (TIR) domain [30-32].

The cellular location and ligands of these TLRs are summarized in Table 1. TLR3, TLR7, TLR8, and TLR9 are localized in intracellular vesicles, including endosomes, whereas others are localized on the cell surface. These TLRs play essential roles in the innate recognition of PAMPs of microbes. TLR2 recognizes a broad range of microbial components, including peptidoglycan, lipoteichoic acids, lipoproteins, lipoarabinomannan, glycophosphatidylinositol anchors, porins, and zymosan [33-39]. TLR2 can form heterodimers with TLR1 or TLR6 to differentially recognize different microbial products. The TLR2-TLR6 complex preferentially recognizes mycoplasma macrophageactivating lipopeptide 2, whereas the TLR2-TLR1 heterodimer more specifically recognizes bacterial lipoproteins and triacyl lipopeptides [40-42]. TLR3 recognizes doublestranded RNA (dsRNA), which is generated during viral replication within infected cells [43]. TLR4 was the first mammalian TLR to be identified [44] and is the major receptor involved in recognizing lipopolysaccharides on the outer membrane of gram-negative bacteria [45]. TLR5 recognizes flagellin, a component of bacterial flagella [46]. TLR7-TLR9 comprised a TLR subfamily with members containing longer extracellular domains $[47,48]$. TLR7 and TLR8 recognize single-stranded RNA viruses, such as the vesicular stomatitis virus or the influenza virus $[49,50]$. TLR9 is essential for the response to microbial unmethylated $\mathrm{CpG}$ DNA. Most CpG sites in mammalian cells, but not in microbes, are methylated; therefore, unmethylated CpG DNA may indicate a microbe infection [51,52]. The natural ligand of TLR10 has not yet been identified.

TLRs also recognize a wide variety of endogenous ligands released from damaged tissues or cells killed during different cancer treatments (Table 1). These endogenous ligands are called DAMPs because they are released following tissue injury and cell death and serve as alarmins to trigger TLR activation, thereby providing an early warning signal to the immune system. DAMPs can be cellular components or stress-induced gene products, including extracellular matrix components, extracellular proteins, intracellular proteins, and nucleic acids $[53,54]$. TLR2 and TLR4 recognize more DAMPs than other TLRs. TLR2 recognizes heat shock proteins (HSPs), Gp96 biglycan, hyaluronic acid, hyaluronan, HMGB1, versican, and monosodium urate crystal [5563]. TLR4 senses HSPs, Gp96, HMGB1, oxidized phospholipids, heparin sulfate, fibrinogen, fibronectin, tenascin-C, $\beta$-defensin 2, hyaluronic acid, and hyaluronan [56, 61-71]. TLR3, TLR7, and TLR8 are activated by host RNA, and TLR9 is activated by host DNA from necrotic cells under special conditions, such as the formation of HMGB1, LL37, or immunoglobulin complex to facilitate ligand interaction with TLR [72-75].

\section{TLR Signaling}

In general, when the extracellular domain of TLR is bound by its ligand, two TLR monomers bridge to form a dimer. The TLR dimer then recruits adaptor proteins from the MyD88 family to initiate downstream signaling pathways (Table 1 and Figure 1). The MyD88 adaptor protein family contains five members: MyD88, TRIF/TICAM1, TIRAP/Mal, TIRP/TRAM, and SRAM [76, 77]. All TLRs except TLR3 signal through a MyD88 dependent pathway, in which a MyD88/IRAK1/IRAK4/TRAF6 complex activates TAK1, which leads to the activation of transcription factors, including NF- $\kappa \mathrm{B}$ and AP-1 [78-80]. TLR3 and TLR4 utilize a MyD88-independent pathway, recruiting TRIF to activate IRF3/7 and NF- $\kappa$ B. IRF3/7 activation involves TBK1IKK $\varepsilon / \mathrm{IKKi}$ complex; NF- $\kappa \mathrm{B}$ and AP-1 activation involves TRAF6 and RIP [81-83].

IL- $1 \beta$ and TNF- $\alpha$ are potent proinflammatory cytokines. TLR agonists and these two cytokines are major mediators of inflammation in the tumor microenvironment [6, 7]. As shown in Figure 1, the IL-1 receptor (IL-1R) utilizes the same signal transduction pathway as that utilized by TLRs: the sequential recruitment of MyD88, IRAK, and TRAF6 to form a complex and TAK activation leading to NF- $\kappa$ B activation. NF- $\kappa \mathrm{B}$ activation downstream of the TNF- $\alpha$ receptor (TNFR) is mediated by TRADD, RIP, and TRAF2. The molecular components involved in TLR/IL-1R and TNFR signaling pathways only partially overlap; nevertheless, the regulation of these pathways is similar and involves the recruitment of adaptor molecules and ubiquitination-mediated regulation of protein expression and interaction. 
TABLE 1: TLRs, their cellular location, ligand recognitions, and adaptor usage.

\begin{tabular}{|c|c|c|c|c|}
\hline Type of TLR & Cellular location & Exogenous ligands (PAMP) & $\begin{array}{l}\text { Endogenous ligands } \\
\text { (DAMP) }\end{array}$ & Signal adaptor \\
\hline $\begin{array}{l}\text { TLR1 (in } \\
\text { association } \\
\text { with TLR2) }\end{array}$ & Cell surface & $\begin{array}{l}\text { Bacteria: triacyl } \\
\text { lipopeptides }\end{array}$ & Unknown & MyD88 \\
\hline $\begin{array}{l}\text { TLR2 (in } \\
\text { association } \\
\text { with TLR1 or } \\
\text { TLR6) }\end{array}$ & Cell surface & $\begin{array}{l}\text { Bacteria: peptidoglycan, } \\
\text { lipoproteins, lipoteichoic } \\
\text { acid, lipoarabinomannan, } \\
\text { glycophosphatidylinositol } \\
\text { anchors, porin; fungi: } \\
\text { zymosan }\end{array}$ & $\begin{array}{l}\text { HSP60, HSP70, Gp96 } \\
\text { biglycan, hyaluronic acid, } \\
\text { hyaluronan, HMGB1, } \\
\text { versican, monosodium } \\
\text { urate crystal }\end{array}$ & MyD88/TIRAP \\
\hline $\begin{array}{l}\text { TLR6 (in } \\
\text { association } \\
\text { with TLR2) }\end{array}$ & Cell surface & $\begin{array}{c}\text { Mycoplasma: } \\
\text { macrophage-activating } \\
\text { lipopeptide } 2\end{array}$ & Versican & MyD88 \\
\hline TLR3 & $\begin{array}{l}\text { Endosomal } \\
\text { compartment }\end{array}$ & Viruses: dsRNA & mRNA & TRIF \\
\hline TLR4 & Cell surface & $\begin{array}{c}\text { Bacteria: LPS } \\
\text { Viruses: RSV fusion protein } \\
\text { Fungi: mannan } \\
\text { Protozoa: } \\
\text { glycoinositolphospholipids }\end{array}$ & $\begin{array}{c}\text { HSP22, HSP 60, HSP70, } \\
\text { HSP72, Gp96, HMGB1, } \\
\text { S100, oxidized } \\
\text { phospholipids, heparin } \\
\text { sulfate, fibrinogen, } \\
\text { fibronectin, tenascin-C, } \\
\text { b-defensin 2, versican, } \\
\text { hyaluronic acid, } \\
\text { hyaluronan }\end{array}$ & $\begin{array}{l}\text { MyD88/TIRAP/ } \\
\text { TRAM/TRIF }\end{array}$ \\
\hline TLR5 & Cell surface & Bacteria: flagellin & Unknown & MyD88 \\
\hline TLR7 & $\begin{array}{l}\text { Endosomal } \\
\text { compartment }\end{array}$ & Viruses: ssRNA & ssRNA (immune complex) & MyD88 \\
\hline TLR8 & $\begin{array}{l}\text { Endosomal } \\
\text { compartment }\end{array}$ & Viruses: ssRNA & ssRNA (immune complex) & MyD88 \\
\hline TLR9 & $\begin{array}{l}\text { Endosomal } \\
\text { compartment }\end{array}$ & $\begin{array}{c}\text { Bacteria: CpG DNA } \\
\text { Viruses: CpG DNA } \\
\text { Protozoa: CpG DNA, } \\
\text { haemozoin }\end{array}$ & $\begin{array}{c}\text { Chromatin IgG complex, } \\
\text { HMGB }\end{array}$ & MyD88 \\
\hline
\end{tabular}

\section{Regulation of TLR Signaling}

Ubiquitination regulates TLR signaling, leading to NF- $\kappa \mathrm{B}$ activation [28, 84]. Ubiquitination is an enzymatic cascade involving three kinds of enzyme: a ubiquitin-activating enzyme (E1), a ubiquitin-conjugating enzyme (E2), and a ubiquitin-protein ligase (E3). Reactions occur with a single ubiquitin (monoubiquitination) or a chain of ubiquitins (polyubiquitination) conjugated to substrates. The specific ubiquitination of signaling molecules is mediated by E3 ligases (E3s) and counteracted by deubiquitinases (DUBs) [8589]. There are approximately 600 E3s and 100 DUBs encoded in the human genome. E3s are characterized by distinct domains and can be divided into three groups: HECT, RING, and F-box. DUBs comprise five families: ovarian tumor proteases, ubiquitin-specific proteases (USPs), ubiquitin Cterminal hydrolases, Josephines, and JAB1/MPN/MOV34 metalloenzymes [86-89]. Seven internal lysine residues (K6, $\mathrm{K} 11, \mathrm{~K} 27, \mathrm{~K} 29, \mathrm{~K} 33, \mathrm{~K} 48$, and K63) and an N-terminal methionine (M1) residue in ubiquitin can be employed to generate eight structurally and functionally different ubiquitin chains. The type of chain depends on which lysine or M1 residue within a target protein/ubiquitin is attached to the $\mathrm{C}$-terminal glycine of the incoming ubiquitin. K48 ubiquitination is involved in protein degradation via a ubiquitin-proteasome dependent pathway and K63 ubiquitination has been linked to protein-protein interaction for signal transduction [8589]. Depending on the type of ubiquitination and target protein, E3 ubiquitin-protein ligases and DUBs can serve as positive or negative regulators of NF- $\kappa \mathrm{B}$ activation following TLR activation.

Tables 2 and 3 list some E3 ubiquitin-protein ligases and DUBs that function as negative regulators of TLR signaling. For example, K48 ubiquitination promotes ubiquitinproteasome degradation of $\mathrm{I} \kappa \mathrm{B}$ by the $\mathrm{SCF}^{\beta \mathrm{TrCP}}-\mathrm{E} 3$ complex and subsequent NF- $\kappa \mathrm{B}$ activation [90, 91]. NF- $\kappa \mathrm{B}$ signaling is negatively regulated by USP11 or USP15-mediated removal of K48-linked ubiquitin chains from $\mathrm{I} \kappa \mathrm{B} \alpha[92,93]$. Triad3A/RNF216 and SOCS1 regulate K48 ubiquitination and proteasomal degradation of TIRAP [94, 95]. SOCS1, COMMD1, and PDLIM2 catalyze K48-linked polyubiquitination and facilitate proteasomal degradation of p65/RelA [96-100]. The K63-linked ubiquitin chain in RIP, TRAF, 
and NEMO provides binding platforms for TAK-TAB and IKK activating complexes, leading to NF- $\kappa \mathrm{B}$ activation. The DUBs, A20, CYLD, USP2, USP4, USP7, USP10, USP18, USP21, and USP25 terminate NF- $\kappa$ B signaling by removing K63-linked ubiquitin chains from signaling molecules [101123]. Furthermore, A20, CYLD, and USP25 remove K63linked ubiquitin chains from TRAF2, TRAF3, and TRAF6. These chains serve as docking platforms for downstream effectors, thereby preventing TRAF2, TRAF3, and TRAF6 from associating with their interaction partners $[101,106,108$, $109,112,119-121]$.

\section{TLR-Activated Inflammatory Responses and Tumor Progression}

Human TLRs are expressed in various immune cells, including dendritic cells, macrophages, monocytes, natural killer cells, B cells, and $\mathrm{T}$ cells. In addition, TLRs are often expressed in tumor cells. Tumors, including lung, breast, liver, colorectal, prostate, pancreatic, melanoma, glioma, and esophageal cancers, have elevated TLR expression [124128] (Table 4). TLRs can be activated in cells by PAMPs of carcinogenic microbes. The best known microbe-related cancers in humans are cervical cancer and oral cancer caused by the human papilloma viruses [129], gastric cancers caused by Helicobacter pylori [130], and hepatic cancers caused by hepatitis B and C viruses [131]. In addition, TLRs in tumor cells can be activated by DAMPs, such as HMGB1, S100, and HSPs, released from dying cells following chemotherapy or radiotherapy [132].

TLR activation increases transcription due to the activation of different transcription factors, including NF- $\kappa \mathrm{B}$, AP-1, and IRFs (Figure 1). NF- $\kappa$ B activates the transcription of multiple proinflammatory genes and is a key mediator of acute and chronic inflammatory responses $[2-4,8]$. The genes of proinflammatory cytokines TNF- $\alpha$ and IL-1 $\beta$ are targets of NF- $\kappa \mathrm{B}$, and these cytokines can activate NF$\kappa \mathrm{B}$ signaling as effectively as TLR ligands. TNF- $\alpha$ and IL$1 \beta$ are released into the tumor environment when TLRs are activated in tumor cells. This in turn activates NF$\kappa \mathrm{B}$, resulting in sustained inflammatory cellular responses and chronic inflammation in the tumor microenvironment $[6,7]$. In addition, NF- $\kappa \mathrm{B}$ also controls the expression of genes involved in cell growth, proliferation, antiapoptosis, angiogenesis, tissue invasion, and metastasis. Typically, NF$\kappa \mathrm{B}$ controls cell growth and proliferation by increasing c-myc and cyclin D1, cyclin D2, cyclin D3, cyclin E, and CDK2, all of which regulate cell cycle progression. It also promotes growth by producing growth factors, including IL-2, IL-6, GM-CSF, and CD40L [133-138]. NF- $\kappa$ B inhibits apoptosis by regulating the antiapoptosis proteins cIAPs, c-FLP, and members of the $\mathrm{Bcl}-2$ family [139]. NF- $\kappa \mathrm{B}$ activation increases angiogenesis in tumors. Tumor cell invasion and metastasis are promoted by the upregulation of angiogenic factors, such as vascular endothelial growth factor; metastasis proteins, such as matrix metalloproteinases, urokinase-type plasminogen activator, MCP-1, MIP-1, and cathepsin B; and chemokines, such as IL8 and CXCL1 in the tumor microenvironment. In addition, the expression of adhesion molecules, such as ICAM-1 and

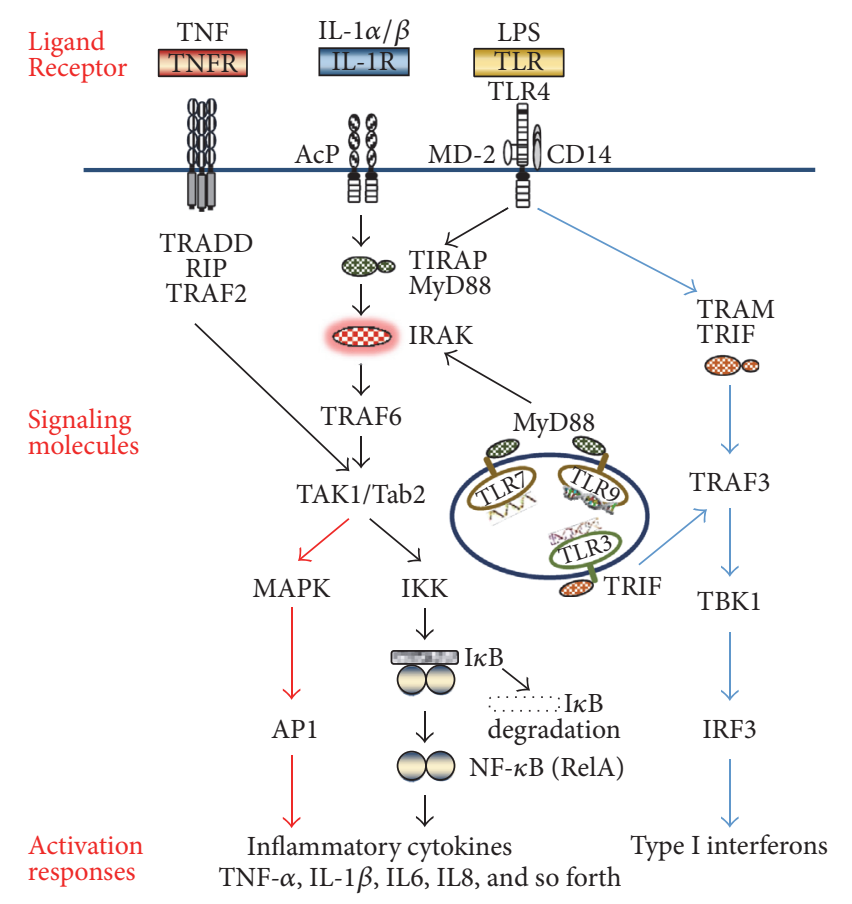

FIGURE 1: TLR and the related TNFR and IL-1R signaling pathways. TLRs utilize a MYD88 dependent pathway (black line) and a TRIF dependent pathway (blue line) to activate NF- $\kappa$ B, AP-1, and IRF3, leading to the production of inflammatory cytokines and type I interferons. IL-1R uses the same set of signaling molecules, and TNFR utilizes the same signaling pathway as TLRs. TLR, tolllike receptor; IL-1R, interleukin-1 receptor; TNFR, tumor necrosis factor receptor; LPS, lipopolysaccharide; TRADD, TNFRSF1A associated via death domain; TIRAP, TIR domain containing adaptor protein; RIP, receptor interacting serine/threonine kinase; IRAK, interleukin-1 receptor associated kinase; TRAF2, TNF receptor associated factor 2; TRAF3, TNF receptor associated factor 3; TRAF6, TNF receptor associated factor 6; TAK1, TGF-beta activated kinase 1; MAPK, mitogen-activated protein kinase 1; IKK, I-kappa $B$ kinase; I $\kappa$ B, NFKB inhibitor; Tab2, TGF-beta activated kinase 1 binding protein 2; TBK1, TANK-binding kinase 1; MYD88, myeloid differentiation primary response 88 ; TRIF, TIR domain containing adapter-inducing interferon- $\beta$; NF- $\kappa \mathrm{B}$, nuclear factor kappa-lightchain-enhancer of activated B cells; AP-1, activator protein 1; IRF3, interferon regulatory factor 3 .

E-selection, is increased in tumor cells [9-11]. Consequently, TLR-activated inflammatory responses promote all stages of tumor progression from tumorigenesis to invasion and metastasis.

Consistent with this, many studies have demonstrated that TLR drives tumor progression. In animal models of HCC and head and neck carcinoma, TLR2 expression in tumor cells correlates positively with tumor progression [140-142]. TLR2 activation in host nontumor cells also has protumor effects. TLR2 depletion in the host cells of mice was reported to reduce the progression of breast, gastric, and intestinal tumors $[143,144]$. The proposed mechanism involved TLR2-derived proinflammatory responses [140]. Similarly, protumor functions were observed following TLR4 activation in tumor cells and nontumor host cells. TLR4 
TABLE 2: Negative regulators of TLR signaling involved in ubiquitination.

\begin{tabular}{lccr}
\hline $\begin{array}{l}\text { E3 ligase or adapter of E3 } \\
\text { ligase complex }\end{array}$ & Target molecules & $\begin{array}{c}\text { Ubiquitin-mediated } \\
\text { modifications }\end{array}$ & Biological function \\
\hline A20 & RIP1, Ubc13 & K48 & Proteolytic degradation \\
Triad3A/RNF216 & TLR3, TLR4, TLR5, TLR9, & K48 & Proteolytic degradation \\
SOCS1 & TIRAP, TRIP, RIP1 & K 48 & Proteolytic degradation \\
PDLIM2 & P65/RelA & K48 & Proteolytic degradation \\
COMMD1 & P65/RelA & K48 & Proteolytic degradation \\
TRIM27 & IKK $\alpha$, IKK $\beta$ & K48 & Proteolytic degradation \\
TRIM38 & TRAF6, TRIF, TAB2/3 & K48 & Proteolytic degradation \\
\hline
\end{tabular}

TABLE 3: Negative regulators of TLR signaling involved in deubiquitination.

\begin{tabular}{lccc}
\hline dUb & Target molecules & Ubiquitin-mediated modifications & Biological function \\
\hline A20 & RIP1, RIP2, TRAF2, TRAF6, MALT1, NEMO & K63 & Signaling termination \\
CYLD & MyD88, TRAF2, TRAF6, TRAF7, RIP1, NEMO & K63 & Signaling termination \\
USP2 $\alpha$ & TRAF6 & K63 & Signaling termination \\
USP4 & TRAF2, TRAF6, TAK1 & K63 & Signaling termination \\
USP7 & TRAF6, NEMO & K63 & Signaling termination \\
USP10 & TRAF6, NEMO & K63/M1 & Signaling termination \\
USP11 & I $\kappa$ B $\alpha$ & K48 & Proteolytic degradation \\
USP15 & I $\kappa$ B $\alpha$ & K48 & Proteolytic degradation \\
USP18 & TAK1, NEMO & K63 & Signaling termination \\
USP21 & RIP1 & K63 & Signaling termination \\
USP25 & TRAF2, TRAF3, TRAF5, TRAF6 & K63/K48 & Signaling termination/proteolytic \\
& & & degradation \\
\hline
\end{tabular}

activation in tumor cells promoted the growth of breast, lung, head and neck, and liver tumors in animal models [140, 145-149]. TLR4 activation in nontumor host cells increased the development of colitis-associated colorectal tumors and diethylnitrosamine-induced liver cancer in animal models $[150,151]$. In addition, TLR5, TLR7, and TLR9 activation promoted tumor growth in different animal models of cancer [152-155]. The promotion of tumor development by TLRs has been supported by clinical data. TLR3 expression in tumor cells has been associated with poor clinical outcome in patients with prostate carcinoma [156]. TLR4 expression in breast and colorectal tumors has also been associated with a poor clinical outcome [157-159]. Strong TLR7 expression was associated with poor prognosis in patients with non-small cell lung cancer and predicted chemotherapy resistance in these patients [160]. Similarly, several studies have revealed an association between TLR9 overexpression in tumor cells and poor prognosis in patients with prostate carcinoma and glioblastoma. TLR9 overexpression has also been associated with an increased tumor grade in breast and ovarian cancers $[156,161,162]$.

In contrast to these protumor effects, some studies have shown antitumor effects of TLR activation. TLR signaling elicited antitumor responses in the immune cells of tumorbearing hosts to facilitate eradication of tumor cells. These results are not discussed in detail here but have been extensively reviewed elsewhere [163-165].

\section{TLR Activation Enhances Stemness in Cancer Cells}

CSCs are a small population of cancer cells found within tumors with high stemness. They are considered to be the cells of origin for tumor initiation and key drivers of malignancy. To achieve this, CSCs exhibit four main properties: (1) capacity to drive neoplastic proliferation and initiate tumors; (2) unlimited capacity for self-renewal; (3) potential to generate more differentiated progeny for heterogeneous cancer cell lineages, and (4) increased resistance to radiation and chemotherapy [12-16]. CSCs can evolve from normal stem cells, which have a long lifespan and are prone to accumulating mutations. Alternatively, CSCs can arise from restricted progenitor or differentiated cancer cells by genetic or epigenetic alterations that activate self-renewal mechanisms and promote stemness [13-16]. CSCs are usually distinguished from other cancer cells by the expression of specific surface markers, including CD133, CD44, CD24, and ALDH. Tumor forming capability can be examined in vitro by analyzing sphere formation in component-defined stem cell medium and low adherence plates. The ability to pump out drugs can be measured by side population analysis using flow cytometry. The tumorigenesis of sorted or enriched CSCs can be investigated using xenograft transplants [12-16].

CSCs play a key role in tumor development, and TLR activation promotes tumor progression; therefore, it is logical 
TABLE 4: TLR expression profile.

\begin{tabular}{|c|c|c|}
\hline Type of TLR & Immune cells & Tumor cells \\
\hline TLR1 & $\begin{array}{l}\text { cDCs, eosinophils, monocytes, } \\
\text { neutrophils, NK cells, pDCs, B cells }\end{array}$ & Myeloma cells \\
\hline TLR2 & $\begin{array}{c}\text { cDCs, monocytes, neutrophils, NK cells, } \\
\text { B cells, T cells }\end{array}$ & $\begin{array}{l}\text { Breast cancer, gastric carcinoma, HCC, intestinal } \\
\text { carcinoma, laryngeal carcinoma, myelogenous } \\
\text { leukemia, oral squamous cell carcinoma }\end{array}$ \\
\hline TLR3 & cDCs, NK cells & $\begin{array}{l}\text { Breast cancer, cervical cancer, CRC, esophageal } \\
\text { squamous cell carcinoma, gastric carcinoma, HNSCC, } \\
\text { HCC, laryngeal carcinoma, lung carcinoma, melanoma, } \\
\text { myelogenous leukemia, neuroblastoma cells, ovarian } \\
\text { cancer, pharyngeal carcinoma (cell lines), prostate } \\
\text { cancer }\end{array}$ \\
\hline TLR4 & $\begin{array}{l}\text { cDCs, eosinophils, monocytes, } \\
\text { neutrophils }\end{array}$ & $\begin{array}{l}\text { Adrenocortical carcinoma, breast cancer, cervical } \\
\text { cancer, CRC, epithelial ovarian cancer, esophageal } \\
\text { squamous cell carcinoma, gastric carcinoma, HNSCC, } \\
\text { intestinal carcinoma, laryngeal carcinoma, HCC, lung } \\
\text { carcinoma, melanoma cell lines, myelogenous } \\
\text { leukemia, neuroblastoma, ovarian cancer, pancreatic } \\
\text { cancer, prostate cancer, skin cancer }\end{array}$ \\
\hline TLR5 & $\begin{array}{c}\text { cDCs, monocytes, neutrophils, NK cells, } \\
\text { T cells }\end{array}$ & $\begin{array}{l}\text { Breast cancer cells, cervical squamous cell carcinoma, } \\
\text { CRC, gastric carcinoma, intestinal carcinoma, ovarian } \\
\text { cancer }\end{array}$ \\
\hline TLR6 & $\begin{array}{c}\text { cDCs, monocytes, neutrophils, NK cells, } \\
\text { B cells }\end{array}$ & \\
\hline TLR7 & $\begin{array}{l}\text { Eosinophils, monocytes, neutrophils, } \\
\text { pDCs, B cells }\end{array}$ & $\begin{array}{l}\text { CRC, esophageal squamous cell carcinoma, lung } \\
\text { carcinoma, myeloma cells, pancreatic ductal } \\
\text { adenocarcinoma }\end{array}$ \\
\hline TLR8 & $\begin{array}{c}\text { cDCs, monocytes, neutrophils } \\
\text { T cells, Tregs }\end{array}$ & CRC, lung carcinoma \\
\hline TLR9 & $\begin{array}{l}\text { Eosinophils, monocytes, neutrophils, } \\
\text { pDCs, B cells }\end{array}$ & $\begin{array}{l}\text { Breast cancer, cervical squamous cell carcinoma, CRC, } \\
\text { esophageal squamous cell carcinoma, gastric } \\
\text { carcinoma, lung carcinoma, myeloma cells, } \\
\text { myelogenous leukemia, ovarian cancer (cell lines), } \\
\text { prostate cancer, renal cell carcinoma }\end{array}$ \\
\hline TLR10 & $\begin{array}{l}\text { Eosinophils, monocytes, neutrophils, } \\
\text { pDCs, B cells, T cells, Tregs }\end{array}$ & CRC \\
\hline
\end{tabular}

HCC, hepatocellular carcinoma; CRC, colorectal carcinoma; NHSCC, head and neck squamous cell carcinoma.

to propose that TLR signaling enhances stemness in cancer cells. Emerging evidence has demonstrated an association between NF- $\kappa \mathrm{B}$ activation by TLR signaling and the expansion, invasion, and tumorigenesis of CSCs. For example, the TLR2-MyD88-NF- $\kappa$ B signaling pathway supports a proinflammatory microenvironment together with the expansion of the $\mathrm{CD} 44^{+} / \mathrm{MyD}^{+} 8^{+}$epithelial ovarian cancer (EOC) stem cells by enhancing self-renewal, as shown by the upregulation of stemness-associated genes. CD $44^{+} / \mathrm{MyD}^{+} 8^{+}$EOC stem cells are responsible for therapeutic resistance and recurrence in patients with EOC [166]. The stimulation of breast cancer cells with the TLR3 ligand poly(I:C) enhanced stemness in cancer cells through the simultaneous activation of $\beta$ catenin and NF- $\kappa \mathrm{B}$ signaling pathways. TLR3 activation promoted the expression of stemness-associated genes, including OCT3/4, NANOG, and SOX2 [167]. Increased stem-like properties were associated with TLR4 expression in HCC, and TLR4 expression in HCC cells correlated significantly with enhanced invasion and migration to the splenic vein in nude mice. In clinical HCC tissues, high TLR4 expression correlated strongly with early recurrence and poor survival, which contributed to poor prognosis of HCC [168]. NF- $\kappa \mathrm{B}$ suppression by $\mathrm{I} \kappa \mathrm{B} \alpha \mathrm{SR}$ in mammary epithelial cells impaired tumorigenesis and diminished tumor-associated macrophage and tumor neoangiogenesis in breast cancer. $\mathrm{I} \kappa \mathrm{B} \alpha \mathrm{SR}$ reduced the number of CD $44^{+} / \mathrm{CD} 24^{-}$stem cells and suppressed NANOG and SOX2 expression. These results indicate that the $\mathrm{NF}-\kappa \mathrm{B}$ pathway controls the tumorigenesis through regulation of stemness of breast cancer cells [169]. TLR4 activation may also activate TWIST1 and promote the formation of stem-like cancer cells in the mouse liver via a cooperation with nanog and STAT3 [170]. TLR9 expanded stem-like androgen-independent prostate cancer cells through NF$\kappa \mathrm{B}$ and STAT3 activation, which in turn upregulated the expression of stemness-associated genes, including NKX3.1, KLF-4, BMI-1, and COL1A1 [153]. 


\section{Interplay between Inflammation and Stemness in Cancer Cells}

NF- $\kappa \mathrm{B}$ is activated by IL- $1 \beta$ and TNF- $\alpha$, which are downstream effectors of TLR activation that also increase stemness in cancer cells. IL- $1 \beta$ and TGF- $\beta$ cooperatively upregulate stemness-associated genes, including NESTIN, BMI1, NOTCH-2, and LIF in glioma cells, thereby increasing invasiveness, drug resistance, and tumor growth in vivo [171]. IL- $1 \beta$ stimulated the expression of the stemness-associated genes NESTIN and BMI-1 in colon cancer cells, promoting sphere formation and increasing drug resistance. The expression of the EMT activator ZEB1 increased in IL-1 $\beta$ induced sphere cells, suggesting a connection between EMT and IL- $1 \beta$-induced CSC self-renewal [172]. In the study, TNF- $\alpha$ upregulated SLUG expression through canonical NF$\kappa \mathrm{B} / \mathrm{HIF} 1 \alpha$ signaling in human breast cancer cells. SLUG upregulation was reported to promote stemness in breast cancer cells, with increased CD44 and Jagged-1 expression, mammosphere growth, and extracellular matrix invasiveness [173]. These findings indicate that NF- $\kappa \mathrm{B}$-mediated inflammatory responses trigged by TLR, IL-1, and TNF- $\alpha$ signaling promote stemness in cancer cells.

In contrast, NF- $\kappa \mathrm{B}$-derived inflammatory responses are high in stemness-enriched cancer cells. In acute myelogenous leukemia, a subpopulation of $\mathrm{CD} 34^{+}$stemness-enriched cells was reported to exhibit high NF- $\kappa \mathrm{B}$ activity, which was not seen in normal hematopoietic stem cells and leukemia cells. This study also identified a TNF- $\alpha$ autocrine pathway forming a NF- $\kappa$ B/TNF- $\alpha$ positive feedback loop that maintained NF$\kappa \mathrm{B}$ activation [174]. TRA-1-60-, CD151-, and CD166-positive stemness-enriched cancer cells purified from human prostate tumors exhibited increased NF- $\kappa \mathrm{B}$ activity and inflammatory gene expression. These cells recapitulated parent tumor heterogeneity in serial xenograft experiments, indicating a hierarchy of human prostate cancer cell development and elevated NF- $\kappa \mathrm{B}$ activity. This may represent a functional pathway of stemness-enriched cancer cells in human prostate cancer [22]. NF- $\kappa \mathrm{B}$ activation is increased in glioblastoma CSCs. p65/RelA translocation into nuclei is higher in these cells than in non-CSCs [21]. A similar phenomenon was observed in ovarian cancer and breast CSCs. NF- $\kappa$ B activation and cytokine expression were elevated in ovarian CSCs. These stemness-enriched ovarian cancer cells were more resistant to anticancer drugs and were more metastatic than non-CSCs [175]. Stemness-enriched breast cancer cells have a CD $44^{+} / \mathrm{CD} 24^{-}$phenotype and higher NF- $\kappa \mathrm{B}$ activity than CD $44^{-} / \mathrm{CD} 24^{+}$breast cancer cells $[176,177]$.

These results indicate a bidirectional interplay between inflammation and stemness in cancer cells. The activation of NF- $\kappa$ B-mediated inflammation by extrinsic stimuli, such as TLR ligands, IL- 1 , and TNF- $\alpha$, induces stemness in cancer cells. The expression of stemness-associated genes is regulated by NF- $\kappa \mathrm{B}$ alone or in cooperation with other signaling pathways, such as STAT3 and NOTCH signaling pathways $[18,19,21]$. The regulation of EMT genes, such as SNAIL, SLUG, and TWIST1, promotes an EMT phenotype, which can initiate the metastasis and dedifferentiation of cancer cells into CSCs $[18,19,173]$. NANOG, SOX2, and POU5F1 are also regulated and are essential for maintaining the pluripotency of CSCs [169, 178-180]. Conversely, increased stemness enhances NF- $\kappa \mathrm{B}$ activation in cancer cells. This may involve the intrinsic dysregulation of inflammatory signaling pathways in cancer cells.

\section{Intrinsically Altered TLR Signaling Enhances Inflammation during the Enrichment of Stemness in Cancer Cells}

This concept was illustrated by a recent report that demonstrated the downregulation of negative regulators of TLR signaling when stemness was enriched in head and neck squamous cell carcinoma (HNSCC) cells [181]. These downregulated negative regulators include COMMD1, SOCS1, and PDLIM2 control TLR signaling through ubiquitination and proteasomal degradation (Figure 1 and Table 2). COMMD1 was initially described as mouse U2afl-rs1 region 1 (Murr1) because it was first discovered in close proximity to U2af1rs1 [182]. This protein lacks catalytic activities and was hypothesized to be an adaptor or scaffold protein with a role in protein-protein interactions $[183,184]$. COMMD1 interacts with the p65/RelA subunit of NF- $\kappa$ B to promote ubiquitination and proteasomal degradation of the subunit $[96,97,185]$. SOCS1 acts as a ubiquitin ligase through its SOCS box domain leading to ubiquitination and proteasomal degradation of p65/RelA. Thus, SOCS1 restricts prolonged p65/RelA transactivation and terminates NF- $\kappa \mathrm{B}$-mediated inflammatory gene expression $[98,186]$. In addition, TLR activation induces the expression of SOCS1, which is phosphorylated by Bruton's tyrosine kinase, and then targets TIRAP for proteasomal degradation [95]. SOCS1 also interacts with IRAK to attenuate TLR signaling [187]. PDLIM2 functions as E3 ubiquitin ligase through its LIM domain and facilitates the polyubiquitination of p65/RelA. PDLIM2 binds p65/RelA through its PDZ domain, sequesters soluble p65/RelA within promyelocytic leukemia protein bodies, and subsequently assists the proteasomal degradation of p65 [181].

COMMD1 was downregulated by miR-205 during the enrichment of stemness in HNSCC cells. The reversal of COMMD1 downregulation correlated with the upregulation of the expression of NF- $\kappa \mathrm{B}$-controlled inflammatory genes, including PTGS2, IL8, IL-1A, CXCL2, IL-6, STAT5B, STAT3, CCL2, IL-1B, CD40, and IL-15. COMMD1 downregulation in cancer cells induced NF- $\kappa \mathrm{B}$ activation and inflammatory responses in cancer cells and the tumor microenvironment. In addition, stemness was increased by reduced COMMD1 expression, as shown by increased sphere-forming capability and elevated expression of stemness-associated genes. COMMD1 downregulation promoted tumorigenicity and tumor growth and increased inflammation and stemness. Furthermore, COMMD1 downregulation was shown in head and neck, breast, lung, colon, gastric, and prostate cancers [181]. These findings indicate that altered TLR signaling drives a positive feedback interplay between inflammation and stemness in cancer cells. 


\section{Conclusion}

Small CSC populations in tumors are key players in malignancy and reduce the success of cancer therapies. Most tumor tissue is removed by chemotherapy, radiotherapy, and surgery, but relapses occur if CSCs remain. Thus, understanding the underlying molecular mechanisms of CSC expansion is crucial for identifying new cancer therapies.

Chronic inflammation has been identified as a major factor for CSC expansion and tumor progression. As reviewed in this article, chronic inflammation can be initiated in the tumor microenvironment by an extrinsic cellular pathway in which TLRs are stimulated by PAMPs of carcinogenic microbes and DAMPs released from cancer cells killed during anticancer treatments. This activates NF- $\kappa \mathrm{B}$-mediated inflammation and increased stemness in cancer cells. Conversely, altered TLR signaling can lead to persistent activation of NF-kB-mediated inflammation during the enrichment of stemness in cancer cells.

This bidirectional positive feedback loop of inflammation and stemness in cancer cells can be a mechanism underlying malignancy and reduced treatment success. Blocking this loop by targeting TLR signaling may represent an effective strategy for inhibiting CSC expansion and tumor progression.

\section{Competing Interests}

The authors declare that they have no conflict of interests regarding the publication of this manuscript.

\section{Acknowledgments}

This work was supported in part by the National Health Research Institutes, Taiwan (Grant IM-105-PP-02) and Ministry of Science and Technology of Taiwan (Grants MOST1043011-B010-001, MOST 104-2314-B-400-024, and MOST 1052320-B-400-013-MY3).

\section{References}

[1] F. Colotta, P. Allavena, A. Sica, C. Garlanda, and A. Mantovani, "Cancer-related inflammation, the seventh hallmark of cancer: links to genetic instability," Carcinogenesis, vol. 30, no. 7, pp. 1073-1081, 2009.

[2] D. Hanahan and R. A. Weinberg, "Hallmarks of cancer: the next generation," Cell, vol. 144, no. 5, pp. 646-674, 2011.

[3] E. Elinav, R. Nowarski, C. A. Thaiss, B. Hu, C. Jin, and R. A. Flavell, "Inflammation-induced cancer: crosstalk between tumours, immune cells and microorganisms," Nature Reviews Cancer, vol. 13, no. 11, pp. 759-771, 2013.

[4] S. I. Grivennikov, F. R. Greten, and M. Karin, "Immunity, inflammation, and cancer," Cell, vol. 140, no. 6, pp. 883-899, 2010.

[5] M. R. Junttila and F. J. de Sauvage, "Influence of tumour microenvironment heterogeneity on therapeutic response," Nature, vol. 501, no. 7467, pp. 346-354, 2013.

[6] B. Hoesel and J. A. Schmid, "The complexity of NF- $\kappa$ B signaling in inflammation and cancer," Molecular Cancer, vol. 12, no. 1, article 86, 2013.
[7] T. Lawrence, "The nuclear factor NF-kappaB pathway in inflammation," Cold Spring Harbor Perspectives in Biology, vol. 1, no. 6, Article ID a001651, 2009.

[8] A. Mantovani, P. Allavena, A. Sica, and F. Balkwill, "Cancerrelated inflammation," Nature, vol. 454, no. 7203, pp. 436-444, 2008.

[9] J. A. DiDonato, F. Mercurio, and M. Karin, "NF- $\kappa$ B and the link between inflammation and cancer," Immunological Reviews, vol. 246, no. 1, pp. 379-400, 2012.

[10] C. Gasparini and M. Feldmann, "NF- $\kappa$ B as a target for modulating inflammatory responses," Current Pharmaceutical Design, vol. 18, no. 35, pp. 5735-5745, 2012.

[11] F. H. Sarkar, Y. Li, Z. Wang, and D. Kong, "NF- $\kappa$ B signaling pathway and its therapeutic implications in human diseases," International Reviews of Immunology, vol. 27, no. 5, pp. 293-319, 2008.

[12] S. Colak and J. P. Medema, "Cancer stem cells-important players in tumor therapy resistance," FEBS Journal, vol. 281, no. 21, pp. 4779-4791, 2014.

[13] J. A. Magee, E. Piskounova, and S. J. Morrison, "Cancer stem cells: impact, heterogeneity, and uncertainty," Cancer Cell, vol. 21, no. 3, pp. 283-296, 2012.

[14] S. D. Mertins, "Cancer stem cells: a systems biology view of their role in prognosis and therapy," Anti-Cancer Drugs, vol. 25, no. 4, pp. 353-367, 2014.

[15] T. Reya, S. J. Morrison, M. F. Clarke, and I. L. Weissman, "Stem cells, cancer, and cancer stem cells," Nature, vol. 414, no. 6859, pp. 105-111, 2001.

[16] J. E. Visvader and G. J. Lindeman, "Cancer stem cells in solid tumours: accumulating evidence and unresolved questions," Nature Reviews Cancer, vol. 8, no. 10, pp. 755-768, 2008.

[17] H. Korkaya, S. Liu, and M. S. Wicha, "Regulation of cancer stem cells by cytokine networks: attacking cancer's inflammatory roots," Clinical Cancer Research, vol. 17, no. 19, pp. 6125-6129, 2011.

[18] S. Shigdar, Y. Li, S. Bhattacharya et al., "Inflammation and cancer stem cells," Cancer Letters, vol. 345, no. 2, pp. 271-278, 2014.

[19] C. Zhou, J. Liu, Y. Tang, and X. Liang, "Inflammation linking EMT and cancer stem cells," Oral Oncology, vol. 48, no. 11, pp. 1068-1075, 2012.

[20] R. Birnie, S. D. Bryce, C. Roome et al., "Gene expression profiling of human prostate cancer stem cells reveals a proinflammatory phenotype and the importance of extracellular matrix interactions," Genome Biology, vol. 9, no. 5, article R83, 2008.

[21] J. M. Garner, M. Fan, C. H. Yang et al., "Constitutive activation of signal transducer and activator of transcription 3 (STAT3) and nuclear factor $\kappa \mathrm{B}$ signaling in glioblastoma cancer stem cells regulates the notch pathway," The Journal of Biological Chemistry, vol. 288, no. 36, pp. 26167-26176, 2013.

[22] V. K. Rajasekhar, L. Studer, W. Gerald, N. D. Socci, and H. I. Scher, "Tumour-initiating stem-like cells in human prostate cancer exhibit increased NF- $\kappa \mathrm{B}$ signalling," Nature Communications, vol. 2, article 162, 2011.

[23] T. Yamashina, M. Baghdadi, A. Yoneda et al., "Cancer stemlike cells derived from chemoresistant tumors have a unique capacity to prime tumorigenic myeloid cells," Cancer Research, vol. 74, no. 10, pp. 2698-2709, 2014.

[24] K. Chen, J. Huang, W. Gong, P. Iribarren, N. M. Dunlop, and J. M. Wang, "Toll-like receptors in inflammation, infection and 
cancer," International Immunopharmacology, vol. 7, no. 10, pp. 1271-1285, 2007.

[25] K. Hoebe, Z. Jiang, P. Georgel et al., "TLR signaling pathways: opportunities for activation and blockade in pursuit of therapy," Current Pharmaceutical Design, vol. 12, no. 32, pp. 4123-4134, 2006.

[26] A. M. Piccinini and K. S. Midwood, "DAMPening inflammation by modulating TLR signalling," Mediators of Inflammation, vol. 2010, Article ID 672395, 21 pages, 2010.

[27] M. P. Belvin and K. V. Anderson, "A conserved signaling pathway: the Drosophila toll-dorsal pathway," Annual Review of Cell and Developmental Biology, vol. 12, pp. 393-416, 1996.

[28] T. Kawai and S. Akira, "Signaling to NF- $\kappa$ B by Toll-like receptors," Trends in Molecular Medicine, vol. 13, no. 11, pp. 460469, 2007.

[29] C. Hashimoto, K. L. Hudson, and K. V. Anderson, “The Toll gene of Drosophila, required for dorsal-ventral embryonic polarity, appears to encode a transmembrane protein," Cell, vol. 52, no. 2, pp. 269-279, 1988.

[30] T.-H. Chuang and R. J. Ulevitch, "Identification of hTLR10: a novel human Toll-like receptor preferentially expressed in immune cells," Biochimica et Biophysica Acta-Gene Structure and Expression, vol. 1518, no. 1-2, pp. 157-161, 2001.

[31] F. L. Rock, G. Hardiman, J. C. Timans, R. A. Kastelein, and J. F. Bazan, "A family of human receptors structurally related to Drosophila Toll," Proceedings of the National Academy of Sciences of the United States of America, vol. 95, no. 2, pp. 588-593, 1998.

[32] K. Takeda and S. Akira, "TLR signaling pathways," Seminars in Immunology, vol. 16, no. 1, pp. 3-9, 2004.

[33] A. O. Aliprantis, R.-B. Yang, M. R. Mark et al., "Cell activation and apoptosis by bacterial lipoproteins through toll-like receptor-2," Science, vol. 285, no. 5428, pp. 736-739, 1999.

[34] P. S. Coelho, A. Klein, A. Talvani et al., "Glycosylphosphatidylinositol-anchored mucin-like glycoproteins isolated from Trypanosoma cruzi trypomastigotes induce in vivo leukocyte recruitment dependent on MCP-1 production by IFNgamma-primed-macrophages," Journal of Leukocyte Biology, vol. 71, no. 5, pp. 837-844, 2002.

[35] C. A. Janeway Jr. and R. Medzhitov, "Innate immune recognition," Annual Review of Immunology, vol. 20, pp. 197-216, 2002.

[36] P. Massari, P. Henneke, Y. Ho, E. Latz, D. T. Golenbock, and L. M. Wetzler, "Cutting edge: immune stimulation by neisserial porins is toll-like receptor 2 and MyD88 dependent," The Journal of Immunology, vol. 168, no. 4, pp. 1533-1537, 2002.

[37] T. K. Means, S. Wang, E. Lien, A. Yoshimura, D. T. Golenbock, and M. J. Fenton, "Human Toll-like receptors mediate cellular activation by Mycobacterium tuberculosis," Journal of Immunology, vol. 163, no. 7, pp. 3920-3927, 1999.

[38] R. Schwandner, R. Dziarski, H. Wesche, M. Rothe, and C. J. Kirschning, "Peptidoglycan- and lipoteichoic acid-induced cell activation is mediated by toll-like receptor 2," The Journal of Biological Chemistry, vol. 274, no. 25, pp. 17406-17409, 1999.

[39] D. M. Underhill, A. Ozinsky, A. M. Hajjar et al., "The Tolllike receptor 2 is recruited to macrophage phagosomes and discriminates between pathogens," Nature, vol. 401, no. 6755, pp. 811-815, 1999.

[40] A. Ozinsky, D. M. Underhill, J. D. Fontenot et al., “The repertoire for pattern recognition of pathogens by the innate immune system is defined by cooperation between Toll-like receptors," Proceedings of the National Academy of Sciences of the United States of America, vol. 97, no. 25, pp. 13766-13771, 2000.
[41] O. Takeuchi, T. Kawai, P. F. Mühlradt et al., "Discrimination of bacterial lipoproteins by toll-like receptor 6," International Immunology, vol. 13, no. 7, pp. 933-940, 2001.

[42] O. Takeuchi, S. Sato, T. Horiuchi et al., "Cutting edge: role of toll-like receptor 1 in mediating immune response to microbial lipoproteins," The Journal of Immunology, vol. 169, no. 1, pp. 1014, 2002.

[43] L. Alexopoulou, A. C. Holt, R. Medzhitov, and R. A. Flavell, "Recognition of double-stranded RNA and activation of NF- $\kappa$ B by Toll-like receptor 3," Nature, vol. 413, no. 6857, pp. 732-738, 2001.

[44] R. Medzhitov, P. Preston-Hurlburt, and C. A. Janeway Jr., "A human homologue of the Drosophila toll protein signals activation of adaptive immunity," Nature, vol. 388, no. 6640, pp. 394-397, 1997.

[45] A. Poltorak, X. He, I. Smirnova et al., "Defective LPS signaling in $\mathrm{C} 3 \mathrm{H} / \mathrm{HeJ}$ and $\mathrm{C} 57 \mathrm{BL} / 10 \mathrm{ScCr}$ mice: mutations in Tlr4 gene," Science, vol. 282, no. 5396, pp. 2085-2088, 1998.

[46] F. Hayashi, K. D. Smith, A. Ozinsky et al., "The innate immune response to bacterial flagellin is mediated by Toll-like receptor 5," Nature, vol. 410, no. 6832, pp. 1099-1103, 2001.

[47] T.-H. Chuang and R. J. Ulevitch, "Cloning and characterization of a sub-family of human toll-like receptors: hTLR7, hTLR8 and hTLR9," European Cytokine Network, vol. 11, no. 3, pp. 372-378, 2000.

[48] X. Du, A. Poltorak, Y. Wei, and B. Beutler, "Three novel mammalian toll-like receptors: gene structure, expression, and evolution," European Cytokine Network, vol. 11, no. 3, pp. 362$371,2000$.

[49] S. S. Diebold, T. Kaisho, H. Hemmi, S. Akira, and C. Reis e Sousa, "Innate antiviral responses by means of TLR7-mediated recognition of single-stranded RNA," Science, vol. 303, no. 5663, pp. 1529-1531, 2004.

[50] F. Heil, H. Hemmi, H. Hochrein et al., "Species-specific recognition of single-stranded RNA via toll-like receptor 7 and 8," Science, vol. 303, no. 5663, pp. 1526-1529, 2004.

[51] A. M. Krieg, "The role of CpG motifs in innate immunity," Current Opinion in Immunology, vol. 12, no. 1, pp. 35-43, 2000.

[52] A. M. Krieg, A.-K. Yi, S. Matson et al., "CpG motifs in bacterial DNA trigger direct B-cell activation,” Nature, vol. 374, no. 6522, pp. 546-549, 1995.

[53] P. Matzinger, "The danger model: a renewed sense of self," Science, vol. 296, no. 5566, pp. 301-305, 2002.

[54] S.-Y. Seong and P. Matzinger, "Hydrophobicity: an ancient damage-associated molecular pattern that initiates innate immune responses," Nature Reviews Immunology, vol. 4, no. 6, pp. 469-478, 2004.

[55] J. F. Curtin, N. Liu, M. Candolfi et al., "HMGB1 mediates endogenous TLR2 activation and brain tumor regression," PLoS Medicine, vol. 6, no. 1, article e10, 2009.

[56] D. Jiang, J. Liang, J. Fan et al., "Regulation of lung injury and repair by Toll-like receptors and hyaluronan," Nature Medicine, vol. 11, no. 11, pp. 1173-1179, 2005.

[57] S. Kim, H. Takahashi, W.-W. Lin et al., "Carcinoma-produced factors activate myeloid cells through TLR2 to stimulate metastasis," Nature, vol. 457, no. 7225, pp. 102-106, 2009.

[58] R. Liu-Bryan, K. Pritzker, G. S. Firestein, and R. Terkeltaub, "TLR2 signaling in chondrocytes drives calcium pyrophosphate dihydrate and monosodium urate crystal-induced nitric oxide generation," The Journal of Immunology, vol. 174, no. 8, pp. 50165023, 2005. 
[59] R. Liu-Bryan, P. Scott, A. Sydlaske, D. M. Rose, and R. Terkeltaub, "Innate immunity conferred by Toll-like receptors 2 and 4 and myeloid differentiation factor 88 expression is pivotal to monosodium urate monohydrate crystal-induced inflammation," Arthritis and Rheumatism, vol. 52, no. 9, pp. 2936-2946, 2005.

[60] L. Schaefer, A. Babelova, E. Kiss et al., "The matrix component biglycan is proinflammatory and signals through Toll-like receptors 4 and 2 in macrophages," The Journal of Clinical Investigation, vol. 115, no. 8, pp. 2223-2233, 2005.

[61] R. M. Vabulas, P. Ahmad-Nejad, C. da Costa et al., "Endocytosed HSP60s use toll-like receptor 2 (TLR2) and TLR4 to activate the toll/interleukin-1 receptor signaling pathway in innate immune cells," The Journal of Biological Chemistry, vol. 276, no. 33, pp. 31332-31339, 2001.

[62] R. M. Vabulas, P. Ahmad-Nejad, S. Ghose, C. J. Kirschning, R. D. Issels, and H. Wagner, "HSP70 as endogenous stimulus of the Toll/interleukin-1 receptor signal pathway," The Journal of Biological Chemistry, vol. 277, no. 17, pp. 15107-15112, 2002.

[63] R. M. Vabulas, S. Braedel, N. Hilf et al., "The endoplasmic reticulum-resident heat shock protein Gp96 activates dendritic cells via the toll-like receptor $2 / 4$ pathway," The Journal of Biological Chemistry, vol. 277, no. 23, pp. 20847-20853, 2002.

[64] A. Biragyn, P. A. Ruffini, C. A. Leifer et al., "Toll-like receptor 4dependent activation of dendritic cells by $\beta$-defensin 2," Science, vol. 298, no. 5595, pp. 1025-1029, 2002.

[65] Y. Imai, K. Kuba, G. G. Neely et al., "Identification of oxidative stress and Toll-like receptor 4 signaling as a key pathway of acute lung injury," Cell, vol. 133, no. 2, pp. 235-249, 2008.

[66] G. B. Johnson, G. J. Brunn, Y. Kodaira, and J. L. Platt, "Receptormediated monitoring of tissue well-being via detection of soluble heparan sulfate by toll-like receptor 4," The Journal of Immunology, vol. 168, no. 10, pp. 5233-5239, 2002.

[67] K. Midwood, S. Sacre, A. M. Piccinini et al., "Tenascin-C is an endogenous activator of Toll-like receptor 4 that is essential for maintaining inflammation in arthritic joint disease," Nature Medicine, vol. 15, no. 7, pp. 774-780, 2009.

[68] Y. Okamura, M. Watari, E. S. Jerud et al., "The extra domain A of fibronectin activates Toll-like receptor 4," The Journal of Biological Chemistry, vol. 276, no. 13, pp. 10229-10233, 2001.

[69] J. S. Park, D. Svetkauskaite, Q. He et al., "Involvement of toll-like receptors 2 and 4 in cellular activation by high mobility group box 1 protein," The Journal of Biological Chemistry, vol. 279, no. 9, pp. 7370-7377, 2004.

[70] S. T. Smiley, J. A. King, and W. W. Hancock, "Fibrinogen stimulates macrophage chemokine secretion through toll-like receptor 4," The Journal of Immunology, vol. 167, no. 5, pp. 28872894, 2001.

[71] B. M. Tesar, D. Jiang, J. Liang, S. M. Palmer, P. W. Noble, and D. R. Goldstein, "The role of hyaluronan degradation products as innate alloimmune agonists," American Journal of Transplantation, vol. 6, no. 11, pp. 2622-2635, 2006.

[72] F. J. Barrat, T. Meeker, J. Gregorio et al., "Nucleic acids of mammalian origin can act as endogenous ligands for Toll-like receptors and may promote systemic lupus erythematosus," The Journal of Experimental Medicine, vol. 202, no. 8, pp. 1131-1139, 2005.

[73] K. Karikó, H. Ni, J. Capodici, M. Lamphier, and D. Weissman, "mRNA is an endogenous ligand for Toll-like receptor 3," The Journal of Biological Chemistry, vol. 279, no. 13, pp. 12542-12550, 2004.
[74] E. A. Leadbetter, I. R. Rifkin, A. M. Hohlbaum, B. C. Beaudette, M. J. Shlomchik, and A. Marshak-Rothstein, "Chromatin-IgG complexes activate B cells by dual engagement of IgM and Tolllike receptors," Nature, vol. 416, no. 6881, pp. 603-607, 2002.

[75] J. Vollmer, S. Tluk, C. Schmitz et al., "Immune stimulation mediated by autoantigen binding sites within small nuclear RNAs involves Toll-like receptors 7 and 8," Journal of Experimental Medicine, vol. 202, no. 11, pp. 1575-1585, 2005.

[76] L. A. J. O’Neill and A. G. Bowie, “The family of five: TIRdomain-containing adaptors in Toll-like receptor signalling," Nature Reviews Immunology, vol. 7, no. 5, pp. 353-364, 2007.

[77] L. A. J. O’Neill, K. A. Fitzgerald, and A. G. Bowie, "The TollIL-1 receptor adaptor family grows to five members," Trends in Immunology, vol. 24, no. 6, pp. 286-289, 2003.

[78] J. Ninomiya-Tsuji, K. Kishimoto, A. Hiyama, J.-I. Inoue, Z. Cao, and K. Matsumoto, "The kinase TAK1 can activate the NIK$\mathrm{I} \kappa \mathrm{B}$ as well as the MAP kinase cascade in the IL-1 signalling pathway," Nature, vol. 398, no. 6724, pp. 252-256, 1999.

[79] K. Yamaguchi, K. Shirakabe, H. Shibuya et al., "Identification of a member of the MAPKKK family as a potential mediator of TGF- $\beta$ signal transduction," Science, vol. 270, no. 5244, pp. 2008-2011, 1995.

[80] C. Wang, L. Deng, M. Hong, G. R. Akkaraju, J.-I. Inoue, and Z. J. Chen, "TAK1 is a ubiquitin-dependent kinase of MKK and IKK," Nature, vol. 412, no. 6844, pp. 346-351, 2001.

[81] L. Deng, C. Wang, E. Spencer et al., "Activation of the I $\kappa$ b kinase complex by TRAF6 requires a dimeric ubiquitin-conjugating enzyme complex and a unique polyubiquitin chain," Cell, vol. 103, no. 2, pp. 351-361, 2000.

[82] K. A. Fitzgerald, D. C. Rowe, B. J. Barnes et al., "LPS-TLR4 signaling to IRF-3/7 and NF- $\kappa \mathrm{B}$ involves the toll adapters TRAM and TRIF," Journal of Experimental Medicine, vol. 198, no. 7, pp. 1043-1055, 2003.

[83] E. Meylan, K. Burns, K. Hofmann et al., "RIP1 is an essential mediator of Toll-like receptor 3-induced NF-kappa B activation," Nature Immunology, vol. 5, no. 5, pp. 503-507, 2004.

[84] Z. J. Chen, "Ubiquitin signalling in the NF- $\kappa$ B pathway," Nature Cell Biology, vol. 7, no. 8, pp. 758-765, 2005.

[85] A. Bibeau-Poirier and M. J. Servant, "Roles of ubiquitination in pattern-recognition receptors and type I interferon receptor signaling," Cytokine, vol. 43, no. 3, pp. 359-367, 2008.

[86] M. J. Clague, C. Heride, and S. Urbé, "The demographics of the ubiquitin system," Trends in Cell Biology, vol. 25, no. 7, pp. 417426, 2015.

[87] E. W. Harhaj and V. M. Dixit, "Regulation of NF- $\kappa$ B by deubiquitinases," Immunological Reviews, vol. 246, no. 1, pp. 107124, 2012.

[88] D. Popovic, D. Vucic, and I. Dikic, "Ubiquitination in disease pathogenesis and treatment," Nature Medicine, vol. 20, no. 11, pp. 1242-1253, 2014.

[89] J. Zinngrebe, A. Montinaro, N. Peltzer, and H. Walczak, "Ubiquitin in the immune system," EMBO Reports, vol. 15, no. 1, pp. 28-45, 2014.

[90] D. C. Scherer, J. A. Brockman, Z. Chen, T. Maniatis, and D. W. Ballard, "Signal-induced degradation of I kappa B alpha requires site-specific ubiquitination," Proceedings of the National Academy of Sciences of the United States of America, vol. 92, no. 24, pp. 11259-11263, 1995.

[91] P. Tan, S. Y. Fuchs, A. Chen et al., "Recruitment of a ROC1-CUL1 ubiquitin ligase by Skp1 and HOS to catalyze the ubiquitination of I $\kappa \mathrm{B} \alpha$," Molecular Cell, vol. 3, no. 4, pp. 527-533, 1999. 
[92] K. Schweitzer, P. M. Bozko, W. Dubiel, and M. Naumann, "CSN controls NF- $\kappa \mathrm{B}$ by deubiquitinylation of $\mathrm{I} \kappa \mathrm{B} \alpha$," The $E M B O$ Journal, vol. 26, no. 6, pp. 1532-1541, 2007.

[93] T. Yamaguchi, J. Kimura, Y. Miki, and K. Yoshida, "The deubiquitinating enzyme USP11 controls an IkappaB kinase alpha (IKKalpha)-p53 signaling pathway in response to tumor necrosis factor alpha (TNFalpha)," The Journal of Biological Chemistry, vol. 282, no. 47, pp. 33943-33948, 2007.

[94] C. Fearns, Q. Pan, J. C. Mathison, and T.-H. Chuang, "Triad3A regulates ubiquitination and proteasomal degradation of RIP1 following disruption of Hsp90 binding," The Journal of Biological Chemistry, vol. 281, no. 45, pp. 34592-34600, 2006.

[95] A. Mansell, R. Smith, S. L. Doyle et al., "Suppressor of cytokine signaling 1 negatively regulates Toll-like receptor signaling by mediating Mal degradation," Nature Immunology, vol. 7, no. 2, pp. 148-155, 2006.

[96] E. Burstein, J. E. Hoberg, A. S. Wilkinson et al., "COMMD proteins, a novel family of structural and functional homologs of MURR1," The Journal of Biological Chemistry, vol. 280, no. 23, pp. 22222-22232, 2005.

[97] G. N. Maine, X. Mao, C. M. Komarck, and E. Burstein, "COMMD1 promotes the ubiquitination of NF- $\kappa \mathrm{B}$ subunits through a cullin-containing ubiquitin ligase," The EMBO Journal, vol. 26, no. 2, pp. 436-447, 2007.

[98] A. Ryo, F. Suizu, Y. Yoshida et al., "Regulation of NF- $\kappa$ B signaling by Pinl-dependent prolyl isomerization and ubiquitinmediated proteolysis of p65/RelA," Molecular Cell, vol. 12, no. 6, pp. 1413-1426, 2003.

[99] T. Tanaka, M. J. Grusby, and T. Kaisho, "PDLIM2-mediated termination of transcription factor NF- $\kappa \mathrm{B}$ activation by intranuclear sequestration and degradation of the p65 subunit," Nature Immunology, vol. 8, no. 6, pp. 584-591, 2007.

[100] T. Tanaka, A. Shibazaki, R. Ono, and T. Kaisho, "HSP70 mediates degradation of the p65 subunit of nuclear factor $\kappa \mathrm{b}$ to inhibit inflammatory signaling," Science Signaling, vol. 7, no. 356, Article ID ral19, 2014.

[101] D. L. Boone, E. E. Turer, E. G. Lee et al., "The ubiquitinmodifying enzyme A20 is required for termination of Toll-like receptor responses," Nature Immunology, vol. 5, no. 10, pp. 10521060, 2004.

[102] S. Daubeuf, D. Singh, Y. Tan et al., "HSV ICP0 recruits USP7 to modulate TLR-mediated innate response," Blood, vol. 113, no. 14, pp. 3264-3275, 2009.

[103] Y.-H. Fan, Y. Yu, R.-F. Mao et al., "USP4 targets TAK1 to downregulate TNF $\alpha$-induced NF- $\kappa \mathrm{B}$ activation," Cell Death and Differentiation, vol. 18, no. 10, pp. 1547-1560, 2011.

[104] X. He, Y. Li, C. Li et al., "USP2a negatively regulates IL- $1 \beta$ - and virus-induced NF- $\kappa$ B activation by deubiquitinating TRAF6," Journal of Molecular Cell Biology, vol. 5, no. 1, pp. 39-47, 2013.

[105] O. Hitotsumatsu, R.-C. Ahmad, R. Tavares et al., "The ubiquitin-editing enzyme A20 restricts nucleotide-binding oligomerization domain containing 2-triggered signals," Immunity, vol. 28, no. 3, pp. 381-390, 2008.

[106] H. Jono, J. H. Lim, L.-F. Chen et al., "NF- $\kappa$ B is essential for induction of CYLD, the negative regulator of NF- $\kappa \mathrm{B}$ : evidence for a novel inducible autoregulatory feedback pathway," The Journal of Biological Chemistry, vol. 279, no. 35, pp. 36171-36174, 2004.

[107] B.-C. Lee, M. Miyata, J. H. Lim, and J.-D. Li, "Deubiquitinase CYLD acts as a negative regulator for bacterium NTHi-induced inflammation by suppressing K63-linked ubiquitination of
MyD88," Proceedings of the National Academy of Sciences of the United States of America, vol. 113, no. 2, pp. E165-E171, 2016.

[108] L. Li, N. Soetandyo, Q. Wang, and Y. Ye, “The zinc finger protein A20 targets TRAF2 to the lysosomes for degradation," Biochimica et Biophysica Acta (BBA)-Molecular Cell Research, vol. 1793, no. 2, pp. 346-353, 2009.

[109] D. Lin, M. Zhang, M.-X. Zhang et al., "Induction of USP25 by viral infection promotes innate antiviral responses by mediating the stabilization of TRAF3 and TRAF6," Proceedings of the National Academy of Sciences of the United States of America, vol. 112, no. 36, pp. 11324-11329, 2015.

[110] X. Liu, H. Li, B. Zhong et al., "Usp18 inhibits NF- $\kappa$ b and NFAT activation during Th17 differentiation by deubiquitinating the TAK1-TAB1 complex," Journal of Experimental Medicine, vol. 210, no. 8, pp. 1575-1590, 2013.

[111] C. Mauro, F. Pacifico, A. Lavorgna et al., "ABIN-1 binds to NEMO/IKK $\gamma$ and co-operates with A20 in inhibiting NF- $\kappa \mathrm{B}$," The Journal of Biological Chemistry, vol. 281, no. 27, pp. 1848218488, 2006.

[112] E. Trompouki, E. Hatzivassillou, T. Tsichritzis, H. Farmer, A. Ashworth, and G. Mosialos, "CYLD is a deubiquitinating enzyme that negatively regulates NF- $\kappa \mathrm{B}$ activation by TNFR family members," Nature, vol. 424, no. 6950, pp. 793-796, 2003.

[113] W. Wang, X. Huang, H.-B. Xin, M. Fu, A. Xue, and Z.-H. Wu, "TRAF family member-associated NF- $\kappa$ B activator (TANK) inhibits genotoxic nuclear factor $\kappa \mathrm{B}$ activation by facilitating deubiquitinase USP10-dependent deubiquitination of TRAF6 ligase," The Journal of Biological Chemistry, vol. 290, no. 21, pp. 13372-13385, 2015.

[114] I. E. Wartz, K. M. O’Rourke, H. Zhou et al., "De-ubiquitination and ubiquitin ligase domains of A20 downregulate NF- $\kappa \mathrm{B}$ signalling," Nature, vol. 430, no. 7000, pp. 694-699, 2004.

[115] A. Wright, W. W. Reiley, M. Chang et al., "Regulation of early wave of germ cell apoptosis and spermatogenesis by deubiquitinating enzyme CYLD," Developmental Cell, vol. 13, no. 5, pp. 705-716, 2007.

[116] N. Xiao, H. Li, J. Luo et al., "Ubiquitin-specific protease 4 (USP4) targets TRAF2 and TRAF6 for deubiquitination and inhibits TNF $\alpha$-induced cancer cell migration," Biochemical Journal, vol. 441, no. 3, pp. 979-986, 2012.

[117] G. Xu, X. Tan, H. Wang et al., "Ubiquitin-specific peptidase 21 inhibits tumor necrosis factor $\alpha$-induced nuclear factor $\kappa \mathrm{B}$ activation via binding to and deubiquitinating receptorinteracting protein 1," The Journal of Biological Chemistry, vol. 285, no. 2, pp. 969-978, 2010.

[118] Z. Yang, H. Xian, J. Hu et al., "USP18 negatively regulates NF$\kappa \mathrm{B}$ signaling by targeting TAK 1 and NEMO for deubiquitination through distinct mechanisms," Scientific Reports, vol. 5, article 12738, 2015.

[119] H. Yoshida, H. Jono, H. Kai, and J.-D. Li, “The tumor suppressor cylindromatosis (CYLD) acts as a negative regulator for tolllike receptor 2 signaling via negative cross-talk with TRAF6 and TRAF7," The Journal of Biological Chemistry, vol. 280, no. 49, pp. 41111-41121, 2005.

[120] B. Zhong, X. Liu, X. Wang et al., "Negative regulation of IL-17mediated signaling and inflammation by the ubiquitin-specific protease USP25," Nature Immunology, vol. 13, no. 11, pp. 11101117,2012

[121] H. Zhong, D. Wang, L. Fang et al., "Ubiquitin-specific proteases 25 negatively regulates virus-induced type I interferon signaling," PLoS ONE, vol. 8, no. 11, Article ID e80976, 2013. 
[122] F. Zhou, X. Zhang, H. van Dams, P. Ten Dijkes, H. Huang, and L. Zhang, "Ubiquitin-specific protease 4 mitigates tolllike/interleukin-1 receptor signaling and regulates innate immune activation," The Journal of Biological Chemistry, vol. 287, no. 14, pp. 11002-11010, 2012.

[123] J. Niu, Y. Shi, J. Xue et al., "USP10 inhibits genotoxic NF- $\kappa$ B activation by MCPIP1-facilitated deubiquitination of NEMO," The EMBO Journal, vol. 32, no. 24, pp. 3206-3219, 2013.

[124] S. González-Reyes, L. Marín, L. González et al., "Study of TLR3, TLR4 and TLR9 in breast carcinomas and their association with metastasis," BMC Cancer, vol. 10, article 665, 2010.

[125] H. D. Park, Y. Lee, Y. K. Oh et al., "Pancreatic adenocarcinoma upregulated factor promotes metastasis by regulating TLR/CXCR4 activation," Oncogene, vol. 30, no. 2, pp. 201-211, 2011.

[126] Y. Sato, Y. Goto, N. Narita, and D. S. B. Hoon, "Cancer cells expressing toll-like receptors and the tumor microenvironment," Cancer Microenvironment, vol. 2, supplement 1, pp. S205-S214, 2009.

[127] I. Sheyhidin, G. Nabi, A. Hasim et al., "Overexpression of TLR3, TLR4, TLR7 and TLR9 in esophageal squamous cell carcinoma," World Journal of Gastroenterology, vol. 17, no. 32, pp. 3745-3751, 2011.

[128] R. Tewari, S. R. Choudhury, S. Ghosh, V. S. Mehta, and E. Sen, "Involvement of TNF $\alpha$-induced TLR4-NF- $\kappa$ B and TLR4HIF- $1 \alpha$ feed-forward loops in the regulation of inflammatory responses in glioma," Journal of Molecular Medicine, vol. 90, no. 1, pp. 67-80, 2012.

[129] N. Muñoz, X. Castellsagué, A. B. de González, and L. Gissmann, "Chapter 1: HPV in the etiology of human cancer," Vaccine, vol. 24, supplement 3, pp. S1-S10, 2006.

[130] J. Parsonnet, G. D. Friedman, D. P. Vandersteen et al., "Helicobacter pylori infection and the risk of gastric carcinoma," The New England Journal of Medicine, vol. 325, no. 16, pp. 1127-1131, 1991.

[131] H. B. El-Serag, "Epidemiology of viral hepatitis and hepatocellular carcinoma," Gastroenterology, vol. 142, no. 6, pp. 1264.e11273.el, 2012.

[132] G. Srikrishna and H. H. Freeze, "Endogenous damageassociated molecular pattern molecules at the crossroads of inflammation and cancer," Neoplasia, vol. 11, no. 7, pp. 615-628, 2009.

[133] M. P. Duyao, A. J. Buckler, and G. E. Sonenshein, "Interaction of an NF- $\kappa$ B-like factor with a site upstream of the c-myc promoter," Proceedings of the National Academy of Sciences of the United States of America, vol. 87, no. 12, pp. 4727-4731, 1990.

[134] D. C. Guttridge, C. Albanese, J. Y. Reuther, R. G. Pestell, and A. S. Baldwin Jr., "NF- $\kappa$ B controls cell growth and differentiation through transcriptional regulation of cyclin D1," Molecular and Cellular Biology, vol. 19, no. 8, pp. 5785-5799, 1999.

[135] T. A. Libermann and D. Baltimore, "Activation of interleukin6 gene expression through the NF- $\kappa \mathrm{B}$ transcription factor," Molecular and Cellular Biology, vol. 10, no. 5, pp. 2327-2334, 1990.

[136] R. Schreck and P. A. Baeuerle, "NF- $\kappa$ B as inducible transcriptional activator of the granulocyte-macrophage colonystimulating factor gene," Molecular and Cellular Biology, vol. 10, no. 3, pp. 1281-1286, 1990.

[137] L. A. Schubert, R. Q. Cron, A. M. Cleary et al., "A T cell-specific enhancer of the human CD40 ligand gene," Journal of Biological Chemistry, vol. 277, no. 9, pp. 7386-7395, 2002.
[138] E. Serfling, R. Barthelmas, I. Pfeuffer et al., "Ubiquitous and lymphocyte-specific factors are involved in the induction of the mouse interleukin 2 gene in T lymphocytes," EMBO Journal, vol. 8, no. 2, pp. 465-473, 1989.

[139] S. Ghosh and M. Karin, "Missing pieces in the NF- $\kappa$ B puzzle," Cell, vol. 109, no. 2, pp. S81-S96, 2002.

[140] L. Farnebo, A. Shahangian, Y. Lee, J. H. Shin, F. A. Scheeren, and J. B. Sunwoo, "Targeting Toll-like receptor 2 inhibits growth of head and neck squamous cell carcinoma," Oncotarget, vol. 6, no. 12, pp. 9897-9907, 2015.

[141] B. Huang, J. Zhao, S. Shen et al., "Listeria monocytogenes promotes tumor growth via tumor cell toll-like receptor 2 signaling," Cancer Research, vol. 67, no. 9, pp. 4346-4352, 2007.

[142] W. Shi, S. Lihui, Q. Li et al., "Suppression of toll-like receptor 2 expression inhibits the bioactivity of human hepatocellular carcinoma," Tumor Biology, vol. 35, no. 10, pp. 9627-9637, 2014.

[143] F. A. Scheeren, A. H. Kuo, L. J. Van Weele et al., "A cell-intrinsic role for TLR2-MYD88 in intestinal and breast epithelia and oncogenesis," Nature Cell Biology, vol. 16, no. 12, pp. 1238-1248, 2014.

[144] H. Tye, C. L. Kennedy, M. Najdovska et al., "STAT3-driven upregulation of TLR2 promotes gastric tumorigenesis independent of tumor inflammation," Cancer Cell, vol. 22, no. 4, pp. 466-478, 2012.

[145] C.-C. Hsiao, P.-H. Chen, C.-I. Cheng et al., "Toll-like receptor-4 is a target for suppression of proliferation and chemoresistance in HepG2 hepatoblastoma cells," Cancer Letters, vol. 368, no. 1, pp. 144-152, 2015.

[146] M. J. Szczepanski, M. Czystowska, M. Szajnik et al., "Triggering of toll-like receptor 4 expressed on human head and neck squamous cell carcinoma promotes tumor development and protects the tumor from immune attack," Cancer Research, vol. 69, no. 7, pp. 3105-3113, 2009.

[147] H. Yang, B. Wang, T. Wang et al., "Toll-like receptor 4 prompts human breast cancer cells invasiveness via lipopolysaccharide stimulation and is overexpressed in patients with lymph node metastasis," PLoS ONE, vol. 9, no. 10, Article ID e109980, 2014.

[148] H. Yang, H. Zhou, P. Feng et al., "Reduced expression of Tolllike receptor 4 inhibits human breast cancer cells proliferation and inflammatory cytokines secretion," Journal of Experimental and Clinical Cancer Research, vol. 29, no. 1, article no. 92, 2010.

[149] W. He, Q. Liu, L. Wang, W. Chen, N. Li, and X. Cao, “TLR4 signaling promotes immune escape of human lung cancer cells by inducing immunosuppressive cytokines and apoptosis resistance," Molecular Immunology, vol. 44, no. 11, pp. 28502859, 2007.

[150] D. H. Dapito, A. Mencin, G.-Y. Gwak et al., "Promotion of hepatocellular carcinoma by the intestinal microbiota and TLR4," Cancer Cell, vol. 21, no. 4, pp. 504-516, 2012.

[151] M. Fukata, A. Chen, A. S. Vamadevan et al., “Toll-like receptor4 promotes the development of colitis-associated colorectal tumors," Gastroenterology, vol. 133, no. 6, pp. 1869-1881, 2007.

[152] J. Cherfils-Vicini, S. Platonova, M. Gillard et al., "Triggering of TLR7 and TLR8 expressed by human lung cancer cells induces cell survival and chemoresistance," The Journal of Clinical Investigation, vol. 120, no. 4, pp. 1285-1297, 2010.

[153] D. Moreira, Q. Zhang, D. M. S. Hossain et al., "TLR9 signaling through NF- $\kappa$ B/RELA and STAT3 promotes tumorpropagating potential of prostate cancer cells," Oncotarget, vol. 6, no. 19, pp. 17302-17313, 2015. 
[154] A. Ochi, C. S. Graffeo, C. P. Zambirinis et al., "Toll-like receptor 7 regulates pancreatic carcinogenesis in mice and humans," Journal of Clinical Investigation, vol. 122, no. 11, pp. 4118-4129, 2012.

[155] E.-J. Song, M.-J. Kang, Y.-S. Kim et al., "Flagellin promotes the proliferation of gastric cancer cells via the Toll-like receptor 5," International Journal of Molecular Medicine, vol. 28, no. 1, pp. 115-119, 2011.

[156] S. González-Reyes, J. M. Fernández, L. O. González et al., "Study of TLR3, TLR4, and TLR9 in prostate carcinomas and their association with biochemical recurrence," Cancer Immunology, Immunotherapy, vol. 60, no. 2, pp. 217-226, 2011.

[157] R. Cammarota, V. Bertolini, G. Pennesi et al., "The tumor microenvironment of colorectal cancer: stromal TLR-4 expression as a potential prognostic marker," Journal of Translational Medicine, vol. 8, article 112, 2010.

[158] X. Chen, F. Zhao, H. Zhang, Y. Zhu, K. Wu, and G. Tan, "Significance of TLR4/MyD88 expression in breast cancer," International Journal of Clinical and Experimental Pathology, vol. 8, no. 6, pp. 7034-7039, 2015.

[159] F.-J. Ma, Z.-B. Liu, X. Hu et al., "Prognostic value of myeloid differentiation primary response 88 and toll-like receptor 4 in breast cancer patients," PLoS ONE, vol. 9, no. 10, Article ID el11639, 2014.

[160] S. Chatterjee, L. Crozet, D. Damotte et al., "TLR7 promotes tumor progression, chemotherapy resistance, and poor clinical outcomes in non-small cell lung cancer," Cancer Research, vol. 74, no. 18, pp. 5008-5018, 2014.

[161] R. Berger, H. Fiegl, G. Goebel et al., “Toll-like receptor 9 expression in breast and ovarian cancer is associated with poorly differentiated tumors," Cancer Science, vol. 101, no. 4, pp. 1059-1066, 2010.

[162] C. Wang, S. Cao, Y. Yan et al., "TLR9 expression in glioma tissues correlated to glioma progression and the prognosis of GBM patients," BMC Cancer, vol. 10, article no. 415, 2010.

[163] M. Dajon, K. Iribarren, and I. Cremer, "Toll-like receptor stimulation in cancer: a pro- and anti-tumor double-edged sword," Immunobiology, vol. 222, no. 1, pp. 89-100, 2017.

[164] M. Voulgarelis and S. Ioannou, "Toll-like receptors, tissue injury, and tumourigenesis," Mediators of Inflammation, vol. 2010, Article ID 581837, 9 pages, 2010.

[165] L. A. Ridnour, R. Y. S. Cheng, C. H. Switzer et al., "Molecular pathways: toll-like receptors in the tumor microenvironmentpoor prognosis or new therapeutic opportunity," Clinical Cancer Research, vol. 19, no. 6, pp. 1340-1346, 2013.

[166] I. Chefetz, A. B. Alvero, J. C. Holmberg et al., "TLR2 enhances ovarian cancer stem cell self-renewal and promotes tumor repair and recurrence," Cell Cycle, vol. 12, no. 3, pp. 511-521, 2013.

[167] D. Jia, W. Yang, L. Li et al., “ $\beta$-Catenin and NF- $\kappa$ B coactivation triggered by TLR3 stimulation facilitates stem celllike phenotypes in breast cancer," Cell Death and Differentiation, vol. 22, no. 2, pp. 298-310, 2015.

[168] W.-T. Liu, Y.-Y. Jing, G.-F. Yu et al., “Toll like receptor 4 facilitates invasion and migration as a cancer stem cell marker in hepatocellular carcinoma," Cancer Letters, vol. 358, no. 2, pp. 136-143, 2015.

[169] M. Liu, T. Sakamaki, M. C. Casimiro et al., "The canonical NF- $\kappa \mathrm{B}$ pathway governs mammary tumorigenesis in transgenic mice and tumor stem cell expansion," Cancer Research, vol. 70, no. 24, pp. 10464-10473, 2010.
[170] D. B. Uthaya Kumar, C. Chen, J. Liu et al., "TLR4 signaling via NANOG cooperates with STAT3 to activate Twistl and promote formation of tumor-initiating stem-like cells in livers of mice," Gastroenterology, vol. 150, no. 3, pp. 707-719, 2016.

[171] L. Wang, Z. Liu, S. Balivada et al., "Interleukin- $1 \beta$ and transforming growth factor- $\beta$ cooperate to induce neurosphere formation and increase tumorigenicity of adherent LN-229 glioma cells," Stem Cell Research and Therapy, vol. 3, no. 1, article 5, 2012.

[172] Y. Li, L. Wang, L. Pappan, A. Galliher-Beckley, and J. Shi, "IL$1 \beta$ promotes stemness and invasiveness of colon cancer cells through Zeb1 activation," Molecular Cancer, vol. 11, article 87, 2012.

[173] G. Storci, P. Sansone, S. Mari et al., “TNFalpha up-regulates SLUG via the NF-kappaB/HIFlalpha axis, which imparts breast cancer cells with a stem cell-like phenotype," Journal of Cellular Physiology, vol. 225, no. 3, pp. 682-691, 2010.

[174] M. L. Guzman, S. J. Neering, D. Upchurch et al., "Nuclear factor- $\kappa \mathrm{B}$ is constitutively activated in primitive human acute myelogenous leukemia cells," Blood, vol. 98, no. 8, pp. 23012307, 2001.

[175] A. B. Alvero, R. Chen, H.-H. Fu et al., "Molecular phenotyping of human ovarian cancer stem cells unravels the mechanisms for repair and chemoresistance," Cell Cycle, vol. 8, no. 1, pp. 158166, 2009.

[176] M. Murohashi, K. Hinohara, M. Kuroda et al., "Gene set enrichment analysis provides insight into novel signalling pathways in breast cancer stem cells," British Journal of Cancer, vol. 102, no. 1, pp. 206-212, 2010.

[177] M. Shipitsin, L. L. Campbell, P. Argani et al., "Molecular definition of breast tumor heterogeneity," Cancer Cell, vol. 11, no. 3, pp. 259-273, 2007.

[178] S. Boumahdi, G. Driessens, G. Lapouge et al., "SOX2 controls tumour initiation and cancer stem-cell functions in squamouscell carcinoma," Nature, vol. 511, no. 7508, pp. 246-250, 2014.

[179] S.-H. Chiou, C.-C. Yu, C.-Y. Huang et al., "Positive correlations of Oct-4 and Nanog in oral cancer stem-like cells and highgrade oral squamous cell carcinoma," Clinical Cancer Research, vol. 14, no. 13, pp. 4085-4095, 2008.

[180] S. M. Kumar, S. Liu, H. Lu et al., "Acquired cancer stem cell phenotypes through Oct4-mediated dedifferentiation," Oncogene, vol. 31, no. 47, pp. 4898-4911, 2012.

[181] D. Yeh, Y. Chen, C. Lai et al., "Downregulation of COMMD1 by miR-205 promotes a positive feedback loop for amplifying inflammatory- and stemness-associated properties of cancer cells," Cell Death and Differentiation, vol. 23, no. 5, pp. 841-852, 2015.

[182] A. Nabetani, I. Hatada, H. Morisaki, M. Oshimura, and T. Mukai, "Mouse U2af1-rs1 is a neomorphic imprinted gene," Molecular and Cellular Biology, vol. 17, no. 2, pp. 789-798, 1997.

[183] P. Bartuzi, M. H. Hofker, and B. van de Sluis, "Tuning NF- $\kappa$ B activity: a touch of COMMD proteins," Biochimica et Biophysica Acta-Molecular Basis of Disease, vol. 1832, no. 12, pp. 2315-2321, 2013.

[184] G. N. Maine and E. Burstein, "COMMD proteins: COMMing to the scene," Cellular and Molecular Life Sciences, vol. 64, no. 15, pp. 1997-2005, 2007.

[185] G. N. Maine and E. Burstein, "COMMD proteins and the control of the NF $\kappa$ B pathway," Cell Cycle, vol. 6, no. 6, pp. 672676, 2007. 
[186] J. Strebovsky, P. Walker, R. Lang, and A. H. Dalpke, "Suppressor of cytokine signaling 1 (SOCS1) limits $\mathrm{NF} \kappa \mathrm{B}$ signaling by decreasing p65 stability within the cell nucleus," The FASEB Journal, vol. 25, no. 3, pp. 863-874, 2011.

[187] R. Nakagawa, T. Naka, H. Tsutsui et al., "SOCS-1 participates in negative regulation of LPS responses," Immunity, vol. 17, no. 5, pp. 677-687, 2002. 


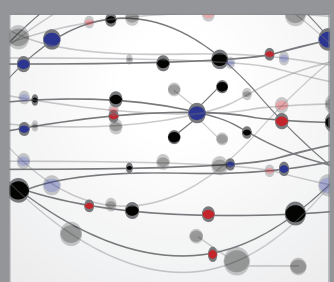

The Scientific World Journal
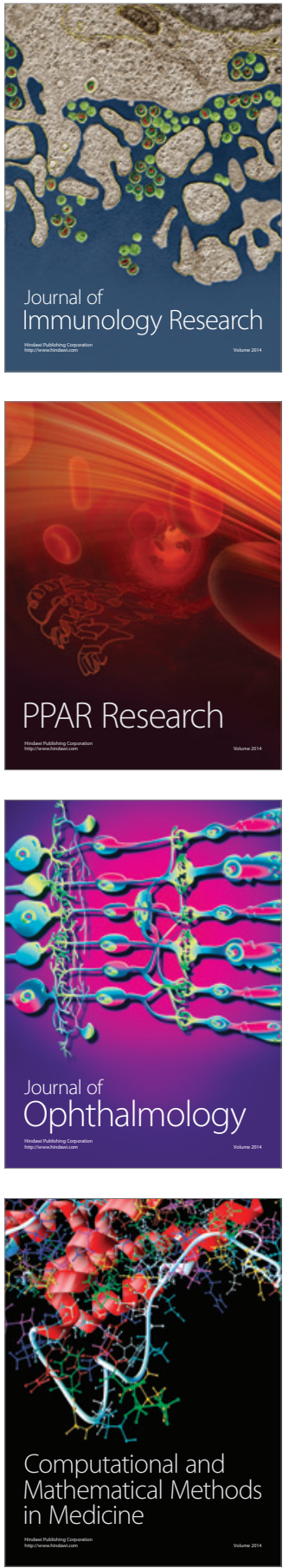

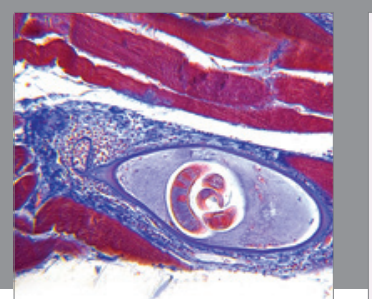

Gastroenterology Research and Practice

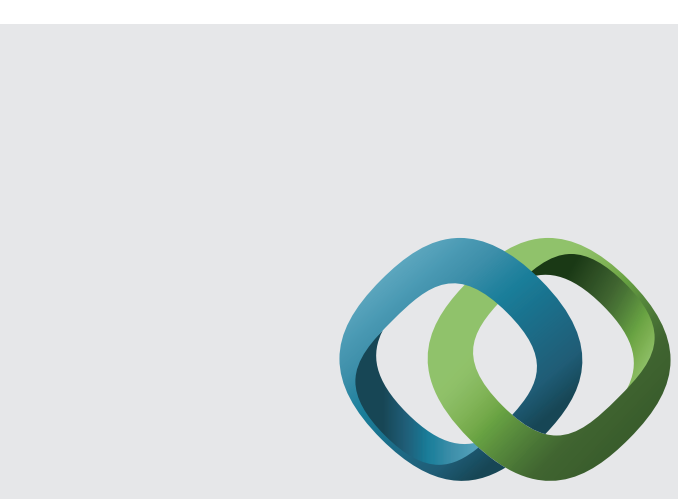

\section{Hindawi}

Submit your manuscripts at

http://www.hindawi.com
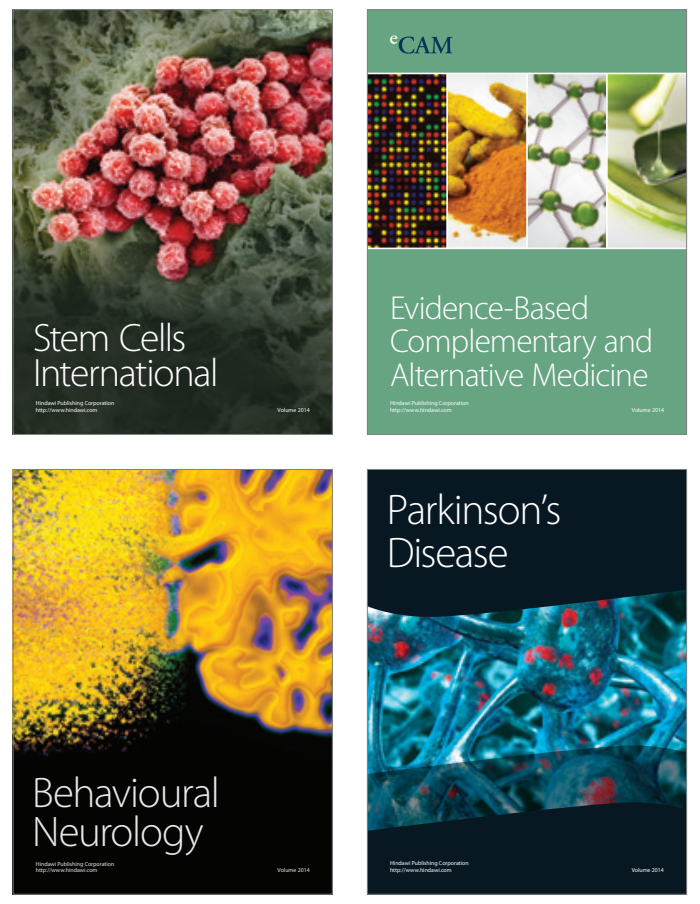
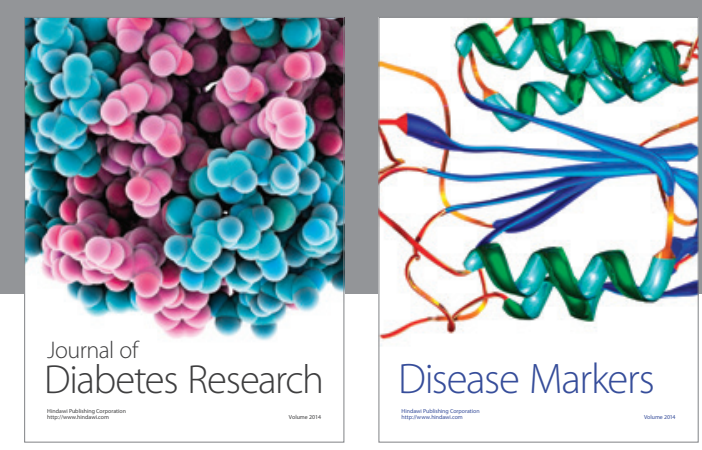

Disease Markers
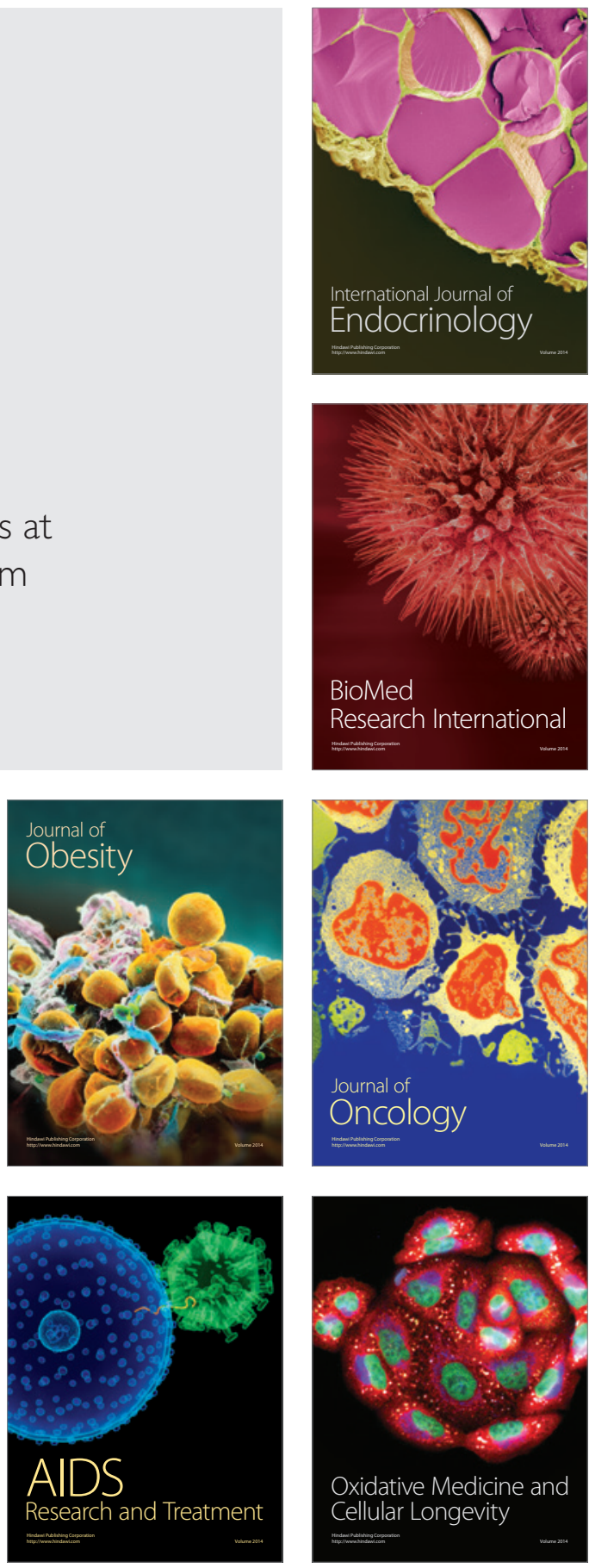